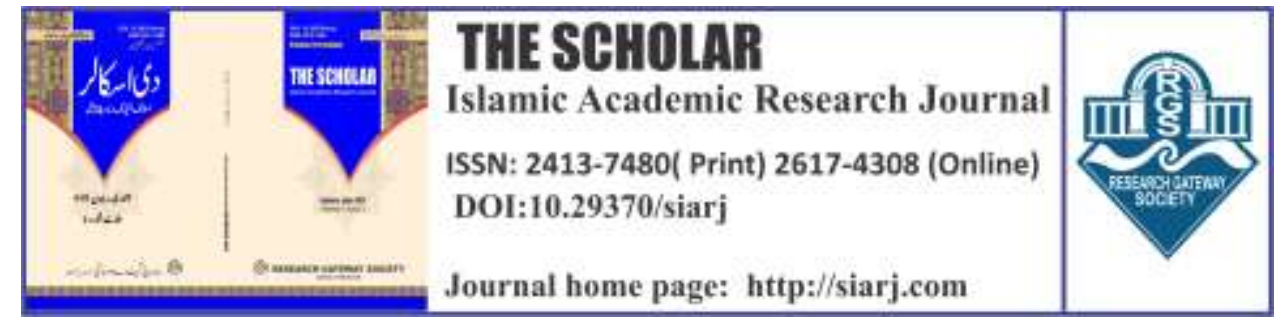

\title{
ISLAMIC PERSPECTIVE OF E-COMMERCE TRANSACTIONS: A SOLUTION TO CONTEMPORARY COMMERCIAL PROBLEMS
}

\author{
1. Anita Ali \\ M.Phil. Hailey College of Commerce, \\ University of the Punjab, Lahore. \\ Email: anitaali530@gmail.com \\ ORCID ID: \\ https://orcid.org/0000-0003-1276-6233
}

\section{Muhammad Ishfaq}

Lecturer, Riphah International University, Faisalabad Campus. Email: m.ishfaqnawaz@gmail.com

ORCID ID:

https://orcid.org/0000-0002-3585-8942

\section{Huma Ali}

MBA, Hailey college of Banking and Finance, University of the Punjab, Lahore. Email: humaali834@gmail.com

ORCID ID: https://orcid.org/0000-0001-7083-2249

To cite this article:

Anita, Muhammad Ishfaq, and Huma Ali. "ISLAMIC PERSPECTIVE OF E-COMMERCE TRANSACTIONS: A SOLUTION TO CONTEMPORARY COMMERCIAL PROBLEMS." The Scholar-Islamic Academic Research Journal 7, No. 2 (December 29, 2021).

To link to this article: https://doi.org/10.29370/siarj/issue13aren4

\begin{tabular}{|c|c|}
\hline Journal & The Scholar Islamic Academic Research Journal \\
\hline & Vol. 7, No. 2 ||July-December 2021 || P.58- 77 \\
\hline Publisher & Research Gateway Society \\
\hline DOI: & 10.29370/siarj/issue13aren4 \\
\hline URL: & https://doi.org/10.29370/siari/issue13aren4 \\
\hline License: & Copyright c 2017 NC-SA 4.0 \\
\hline Journal homepage & www.siarj.com \\
\hline Published online: & $2021-12-29$ \\
\hline
\end{tabular}
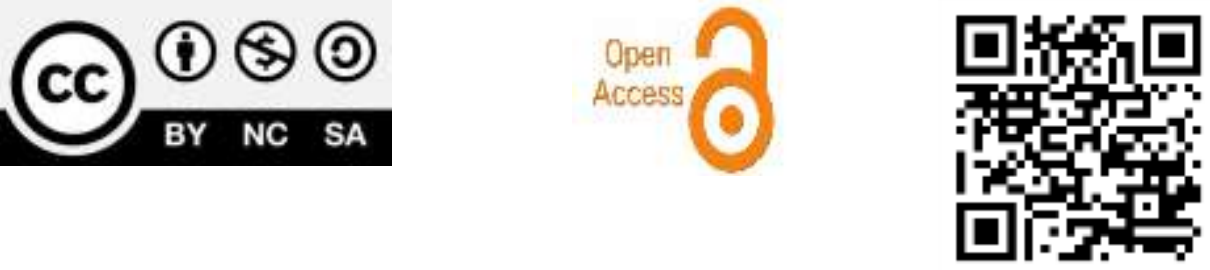
THE SCHOLAR (July-December 2021)

\title{
ISLAMIC PERSPECTIVE OF E-COMMERCE TRANSACTIONS: A SOLUTION TO CONTEMPORARY COMMERCIAL PROBLEMS
}

\author{
Anita Ali, Muhammad Ishfaq, Huma Ali
}

\begin{abstract}
:
E-commerce is a crucial aspect of the economy for firms that offer their goods or services online. E-commerce allows sellers or companies to target a wider audience than traditional retail. In the world of corporate technology, there has been tremendous expansion in recent decades. Technology is used by enterprises to gain a better position in the marketplace. The purpose of this research paper is to investigate Islamic viewpoints on e-commerce, notably in terms of transactions. It will also highlight the rights of the seller and customer according to Islamic law. The ethical perspective of E-Commerce in Islam will be investigated to explicit Muslims about how they might benefit from this new form of business. E-commerce contracts will also be analyzed in Islamic contract law that is crucial for business development and life improvement. This paper will attempt to set out the paradigm for Islamic E-commerce, emphasizing the important success elements and ethics that will produce positive outcomes and provide a solution to the contemporary commercial problems.
\end{abstract}


KEYWORDS E-commerce, Transactions, Issues, Islam

\section{INTRODUCTION:}

The Online world gives the impression that the physical universe has no boundaries. People may use communication technology to connect, gather data, and conduct commercial transactions in only a few taps. Customers can purchase the product and digital things via the internet and have them delivered to their homes or ordered online. The E-Commerce epoch is the label given to this period. Islam is a universal religion that provides a complete code of life. Islam encourages the positive and constructive use of technology. The rate of E-commerce transactions is rapidly increasing all over the globe. Islam as dynamic and progressive religion provides comprehensive guidelines for E-commerce and its transactions.

\section{RESEARCH METHODOLOGY:}

In this paper, the qualitative research method is applied to elaborate the Islamic perspective of E-commerce transactions. Various libraries, chronicles, reports, books, articles, and repositories are consulted. So, this is library-based descriptive research that provides an analysis of E-commerce legitimacy and its transactions under Islamic law.

\section{IMPORTANCE OF RESEARCH:}

While E-Trade is becoming more popular all over the world, the question arises that if this particular form of commerce is permitted in Islam and if it is permitted, then what are its boundaries and ethical principles. There is a dire need to find the answer to these questions and highlight the Islamic ethical perspective of E-commerce as it can provide an exclusive solution to contemporary commercial problems. This 
research is to investigate Sharia viewpoints on e-commerce, notably in terms of trade, as well as supplier and client interests.

\section{E-COMMERCE:}

E-commerce, often referred to as electronic commerce or online shopping, is the purchasing and selling of goods and services through the electronic media or worldwide web, as well as the financial and other transfers required to complete these operations. The expansion of Electronic Transactions has been propelled by the worldwide accessibility of the Internet for the interchange of activities between producers and consumers. The practice of purchasing and selling products and services online through computerized financial activities using online services, networks, and other modern devices is referred to as electronic commerce or e-commerce.

Electronic commerce is commonly used in reference to the selling of real goods, but it could also refer to any type of business transaction that is made possible by the internet. ${ }^{1}$ E-commerce, as defined by The Economic Cooperation and Development (OECD), is a business or activity that generates value both within a firm (internally) and with suppliers and customers over networks that use publicly available guidelines established through an open regulatory process such as the Internet ${ }^{2}$

According to a guide on E-commerce, It is the process of transacting

${ }^{1}$ Nawarathna Banda, "E-Commerce," ResearchGate, no. January (2019), https://www.researchgate.net/publication/330496230_Ecommerce.

2 Alexander Böhmer, "Economic and Social Impact of E-Commerce," Handbook of Transnational Economic Governance Regimes, OECD Digital Economy Papers, no. 40 (2009): 227-41, https://doi.org/10.1163/ej.9789004163300.i-1081. 
business and services via the Internet using technologies such as the world wide web, electronic communications, emails, e-cash, and mobile payments, etc. ${ }^{3}$ Others make the argument that E-Commerce does not seem to be limited to Online transactions and can also be inferred from other mediums of expression such as mobile, telex, and telegraphic. To simplify things, E-Commerce can be defined as doing online business, which might include acquiring information, communicating, and exchanging with clients and stakeholders via the internet.

\section{SIGNIFICANCE OF E-COMMERCE:}

In the last few decades, the rise of E-Commerce has resulted in significant complexity and diversity in its form and uses. E-commerce is the use of ICT infrastructure to connect economic functions and procedures in order to cut processing costs and obtain a business edge. E-commerce has the potential to connect third-world countries to the rest of the globe, removing them from the status of outsiders. E-commerce, for example, can provide more individuals with access to products and administrations that were previously unavailable. Another advantage is that online stores are available around the clock each day, seven days per week. As the framework for e-commerce evolves, previously unavailable services become accessible. The pervasive functioning of E-Commerce can provide developing countries with many potential benefits. ${ }^{4}$

\footnotetext{
${ }^{3}$ Joseph, Deborah. A Guide to E-Commerce. Available at: http://www.ilr.cornell.edu/library/reference/guides/ecom merce/.

4 Norazlina Zainul, Fauziah Osman, and Siti Hartini Mazlan, "ECommerce from an Islamic Perspective," Electronic Commerce Research and Applications 3, no. 3 (2004): 280-93, https://doi.org/10.1016/j.elerap.2004.01.002.
} 
Information technology has reshaped how the world communicates and receives information during the last two decades. The rise of Islamic platforms on the Web, several of which are committed to the Education system and dissemination, some are of a more commercial or entertainment type, demonstrates some Muslims' enthusiasm to adopt such innovation. ${ }^{5}$

The Internet, or emerging media channel, bridges the gap between the actual and virtual worlds. Because of the Web, the world has become truly globalized. People may use the Internet to buy footwear, accessories, and electrical equipment, as well as obtain information and learn about different societies and regions. With the advancement of the Internet, it has become a means of not only connecting and gathering information but also of ordering items and having them delivered to our homes. ${ }^{6}$

${ }^{5}$ Zainul, Osman, and Mazlan.

6 Nuradli Ridzwan Shah Mohd Dali et al., "E-Commerce in Islamic Perspectives. The Theoretical Framework, Key Success Factor and Challenges for Islamic E-Commerce," Knowledge Management International Conference $2004 \quad$ (KMICE) $2004 \quad$ (2004), https://doi.org/10.1073/pnas.1112034108. 


\section{Islamic Perspective of E-Commerce Transactions: A Solution to Contemporary Commercial Problems}

\section{E-Commerce and Islam:}

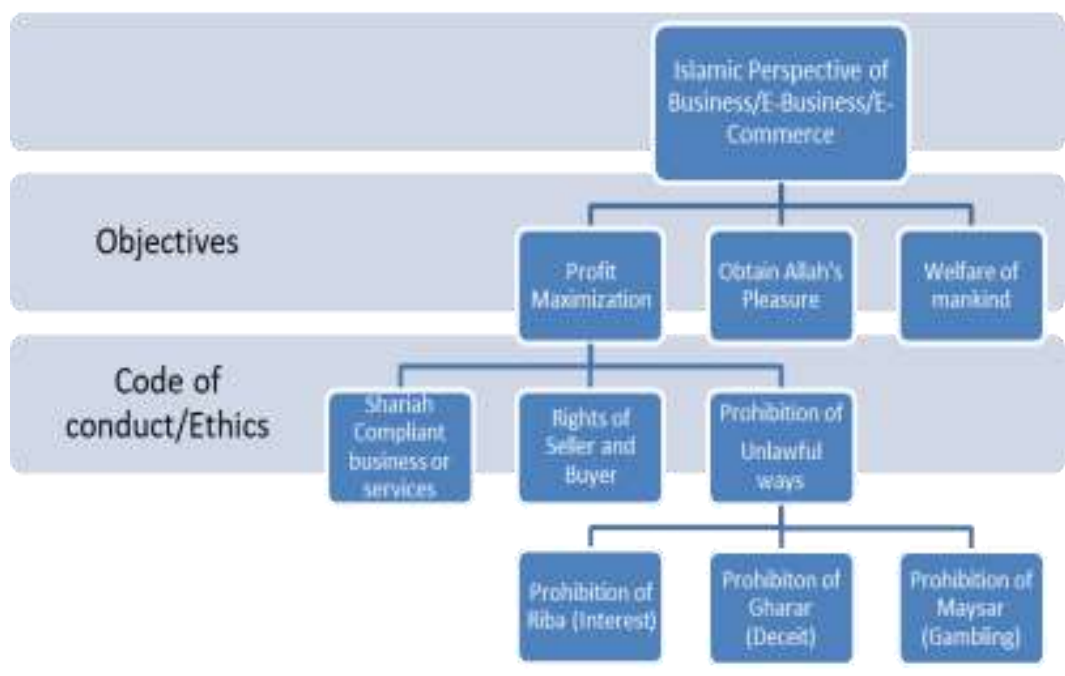

E-commerce objectives in Islam are extensive as they are not limited to obtaining profit from the business, rather a Muslim struggle to obtain Allah's pleasure from his business dealings and transactions. Islam does not promote monasticism like Buddhism and Christianity, rather it motivates to involve in economic activities and the welfare of human beings. It can cause "Falah" (Success), as mentioned in Quran:
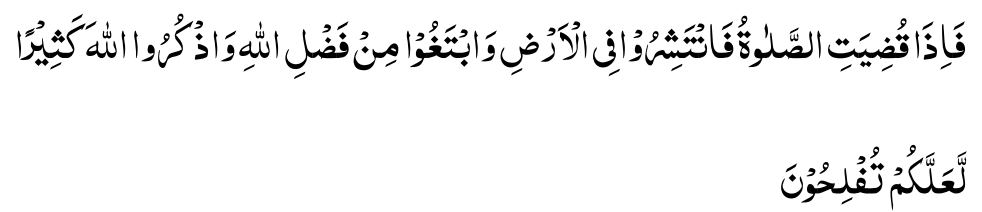

Then once the Salah is over, disperse in the land, and 


\section{Islamic Perspective of E-Commerce Transactions: A Solution to Contemporary Commercial Problems}

seek the grace of Allah(by earning), and remember

Allah abundantly, so that you may be successful ${ }^{7}$.

So, according to Islam, E-commerce targets are three-fold, Profit Maximization, Obtaining Allah's pleasure, and the welfare of people.

\section{THE LEGITIMACY OF E-COMMERCE-ISLAMIC LAW:}

The Quran is a guidebook that contains universal ideas that can be applied to all eras and settings. The Quran contains standards and procedures for many aspects of life, including (by comparison) the field of information technology. IT and effective learning are inextricably linked. Since the very first revelation, Islam has emphasized the need of seeking both supernatural and mundane education. Corollary, information technology (IT) is one of the fields of learning that Muslims should investigate and put to good use.
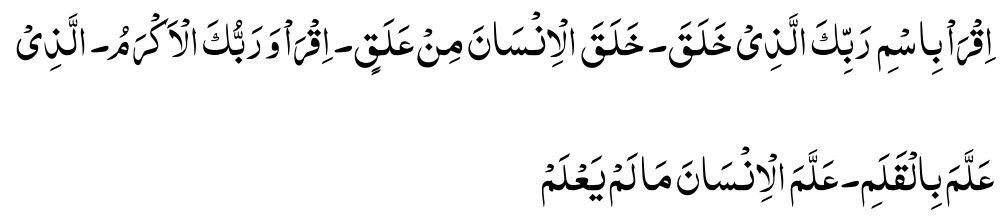

Read with the name of your Lord who created (everything). He created man from a clot of blood. Read, and your Lord is the most gracious. who imparted knowledge utilizing the pen .He taught man

${ }^{7}$ Al-Quran 62:10 


\title{
Islamic Perspective of E-Commerce Transactions: A Solution to Contemporary Commercial Problems
}

\author{
what he did not know ${ }^{8}$.
}

So, It is one of the objectives in Islam that it encourages to learn all the sciences that are useful for mankind. An important transformation in human's lives has been brought about by the advancement of technology, the move to a World Wide Web dominated community. The way in which people conducted transactions, trade, and business in this dynamic world of competition is one of the primary sectors that has been drastically altered. Muslims are, unfortunately, left behind in learning this knowledge and utilizing the technology. Muslims all over the world can get more benefit from this advancement if they keep in mind Islamic objectives and ethical patterns of business. As a comprehensive religion, Islam promotes business trade and commerce.

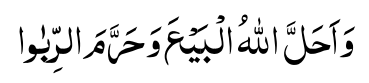

\section{Allah has permitted business, and prohibited riba (Interest). ${ }^{9}$}

E-commerce is an exchange of things and services but the medium is online or electronic. So, for E-commerce legitimacy, the same parameters are applied as are functional for Islamic business and Islamic law of contract as these parameters assure interests protection of both parties (buyer and sellers) and reject loss.

All trading and commerce transactions in Islam are permissible in Islam provided that they are

${ }_{9}^{8}$ Al-Quran 96:5

9 Al-Quran 275:2 


\section{Islamic Perspective of E-Commerce Transactions: A Solution to Contemporary Commercial Problems}

- In compliance with Shariah injunctions

- Protect the interest of both contracting participants (Buyer and Seller)

- Free of prohibited elements and conditions such as Riba(Interest), Gharar(Fraud), Maysar (Gambling) ${ }^{10}$

It is necessary according to Shariah that the thing that is being offered must be present and over the seller. But in online, there are cases when it is not so. But in such cases, some of the E-commerce forms that have a resemblance to Bai-as-Salam, are permissible according to Muslim Scholars. Such as in the $2^{\text {nd }}$ Applied International Business Conference Bai-as-Salam and E-commerce were discussed from Shariah's perspective.

${ }^{11}$ In the Muslim world, research about to complexities of E-commerce is continued but the need of the time is to widen the scope in compliance with Shariah.

\section{ISLAMIC ETHICAL PATTERNS FOR E-COMMERCE:}

Islam is the religion that governs and supervises all aspects of life. It is not to be treated as a personalized, private issue, separate from one's economic systems. It is a pragmatic rule that controls life in all of its realms, not just a set of doctrines or a set of sacred rituals. Its laws are as efficient in our

\footnotetext{
${ }^{10}$ Marjan Muhammad, Muhd Rosydi Muhammad, and Khalil Mohammed Khalil, "Towards Shari'ah Compliant E-Commerce Transactions: A Review of Amazon.Com," Middle East Journal of Scientific Research 15, no. 9 (2013): 1229-36, https://doi.org/10.5829/idosi.mejsr.2013.15.9.11176.

11 Ainnur Hafizah, Anuar Mokhtar, and Mohd Zulkifli Muhammad, "Bai As-Salam and E-Commerce: A Comparative Analysis From Shariah Perspectives," Proceedings of the 2nd Applied International Business Conference (AIBC2013) 7, no. December (2013): 522-29.
} 


\section{Islamic Perspective of E-Commerce Transactions: A Solution to Contemporary Commercial Problems}

family life and social connections as they are in our commercial activity. Economical abuse, like individual deceit, is condemned in Islam.

\section{SHARIA-COMPLIANT E-BUSINESS OR SERVICES:}

Every business transaction in business, whether in a physical or digital context, such as e-commerce, can form a legitimate contract of buying and selling, according to Shariah. A transaction must meet specific standards set forth by Shariah values to be valid and appropriate. Though ecommerce is a relatively modern phenomenon, it refers to almost the same procedure as conventional trade and commerce in Islam, as it entails agreements to sell and buy items from one entity to another. As a result, all e-commerce activities must comply with the standards and ethics of Islamic commercial contracts, which also primarily aims to protect the best interest and eliminate damages of groups involved in the transactions, thus boosting Shariah-based business and commerce guidelines that are rooted in justice as one of Shariah's primary goals. ${ }^{12}$

So, all the E-commerce transactions and contracts must be in accordance with Shariah. First of all, the product or service that is being sold or bought must be permissible in Islam. As Quran encourages to eat and consume Halal,

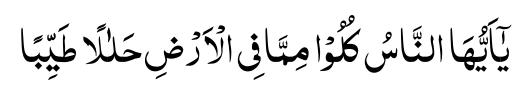

O people, eat permissible good things out of what lies

12 Rositah Kambol, "E-Commerce in the Context of Islamic Law of Contract of Sale," Journal of Law \& Governance 1, no. 1 (2018): 36-48. 
The Scholar Islamic Academic Research Journal

Vol. 7, No. 2 || July-December 2021 || P. 58-77

https://doi.org/10.29370/siarj/issue13aren4

in the earth. ${ }^{13}$

Man eats whatever he earns and earning must be in the halal product by valid means. Islam describes the great virtue of halal business and those who work hard to earn halal.

The Messenger of Allah upheld all types of business exchanges that were premised on equality and fair perform for all, and expressly forbidden all forms of business operations that were either inequitable, or going to result in squabbles and legal battles, or sort of resembles gambling, or enclosed an aspect of Interest or deception. In the Prophetic era, the principle of Adal (Justice) was rooted in every form of business transition. ${ }^{14}$

PROHIBITION OF RIBA (INTEREST):

Interest essentially translates to "Interest on loans," or unfair, exploitative earnings in financial transactions. In English, the Arabic term "Riba" actually means "spike" or "increase". In a traditional corporate structure, a creditor earns a lot of money in the format of riba by providing loans to people or transferring products. The Quran expressly forbids riba, and because the Quran is the authoritative guiding light, all Believers, along with all ideologies, believe that riba is prohibited in every commerce or enterprise. That's because commerce and interest are opposed. Revenue is earned in commerce by innovation, entrepreneurship, effectiveness, and manual labor.

The profits in interest, on the other hand, are not acquired by sustained

${ }^{13}$ Al-Quran 168:2

14 Zainul, Osman, and Mazlan, "E-Commerce from an Islamic Perspective." 
The Scholar Islamic Academic Research Journal

Vol. 7, No. 2 || July-December 2021 || P. 58-77

https://doi.org/10.29370/siarj/issue13aren4

effort or any other future growth activity. It is economic rent, rather than the benefit of work, that is regarded as unfair. Furthermore, interest is set, while profitability varies. In commerce, there seems to be a danger of damage as well, but within interest, the borrower receives his specified amount regardless of whether the borrower makes a gain or loses money. Interest is banned by Allah, but commerce is acceptable. As illustrated here, Quran emphasizes the ban of interest
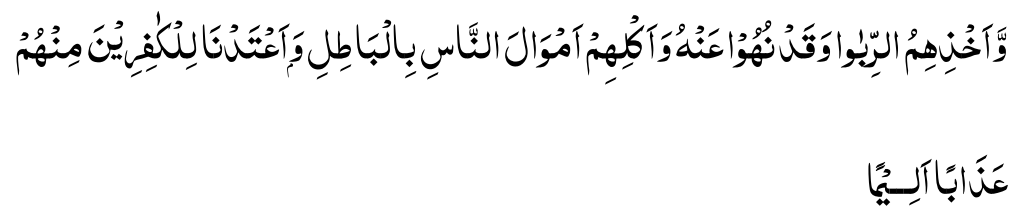

and for their charging Riba (usury or interest) while they were forbidden from it, and for their devouring of the properties of the people by false means. We have prepared, for the disbelievers among them, a painful punishment $^{15}$.

Allah has permitted commerce and trade but prohibited Riba (Interest). Islam forbids every unjust and unfair means in business. So, E-commerce is legitimate avoiding Riba and the rest of the unfair means that are barred by Islam.

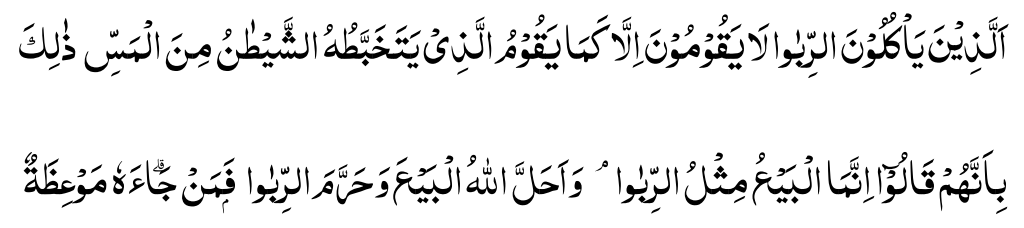

${ }^{15}$ Al-Quran 161:4 


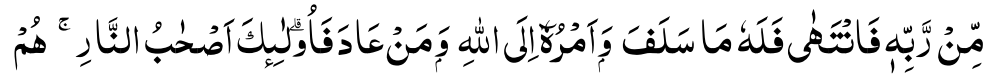

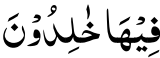

Those who take riba (usury or interest) will not stand but as stands the one whom the demon has driven crazy by his touch. That is because they have said: Business is but like riba ,".while Allah has permitted Business and prohibited riba. So, whoever receives advice from his Lord and desists (from indulging in riba), then what has passed is allowed for him, and his matter is up to Allah. As for the ones who revert, those are the people of Fire. There they will remain forever ${ }^{16}$.

It clearly shows that Riba (Interest) is forbidden in Islam. Islam forbids interest in its every form. As mentioned in Quran:

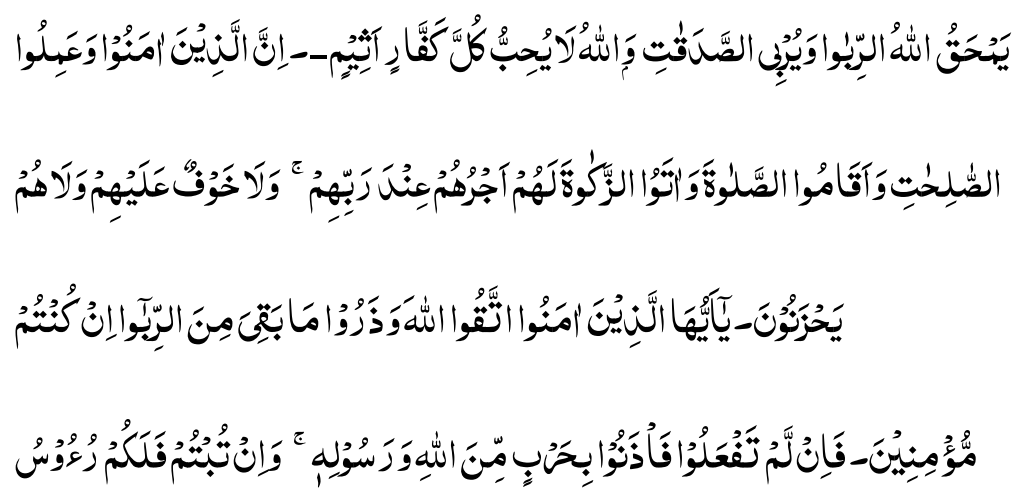

${ }^{16}$ Al-Quran 275:2 


\begin{abstract}
Allah destroys riba and nourishes charities, and Allah does not like any sinful disbeliever. Surely those who believe and do good deeds, and establish Salah (prayer) and pay Zakah will have their reward with their Lord, and there is no fear for them, nor shall they grieve. O you who believe, fear Allah, and give up what remains of riba if you are believers. But if you do not (give it up), then listen to the declaration of war from Allah and His Messenger. However, if you repent, yours is your principal. Neither wrong nor be wronged $^{17}$.
\end{abstract}

These Quranic verses clearly show that how much Islam is, against interest because it destroys economic equilibrium and exploits the deprived groups of society.

Riba (Interest) will arise in an e-commerce operation as a result of the production and buy procedure, as well as the e-commerce payment method, which permits the adoption of E-payment for digital purchasing. The use of bank cards (like credit cards and debit cards) as a payment method in an online transaction raises several issues in Shariah legally. In many scenarios, using a credit card comes with a set of criteria known as riba, which can arise in one of two scenarios. The first one is the costs of

${ }^{17}$ Al-Quran 280:2 
The Scholar Islamic Academic Research Journal

Vol. 7, No. 2 || July-December 2021 || P. 58-77

https://doi.org/10.29370/siarj/issue13aren4

the delayed payment for the late payment, and the second is the everyday interest on the loan repayment sum. In either case, interest paid above and above the original amount is referred to as riba, and it is illegal (haram). Choosing a form of money-transfer system that conforms to the Shariah concept would be a difficulty for Islamic e-commerce in combating interest.

\section{PROHIBITION OF MAYSAR (GAMBLING):}

Maysar (Gambling) is a word that refers to gambling or speculation. It is forbidden in Islamic financial institutions since it is based on luck rather than constructive action. Maysir and Qimar are two types of gaming that Islam considers to be completely unequal unsatisfactory. Many Islamic scholars consider maysar to be betting or any online gambling (such as lottery, raffles, casino-style games, and riding on the results of animal competitions). These are all looking for a way to make money by taking calculated risks. Islam prohibits both gambling games and casinos, as indicated in the Quran:

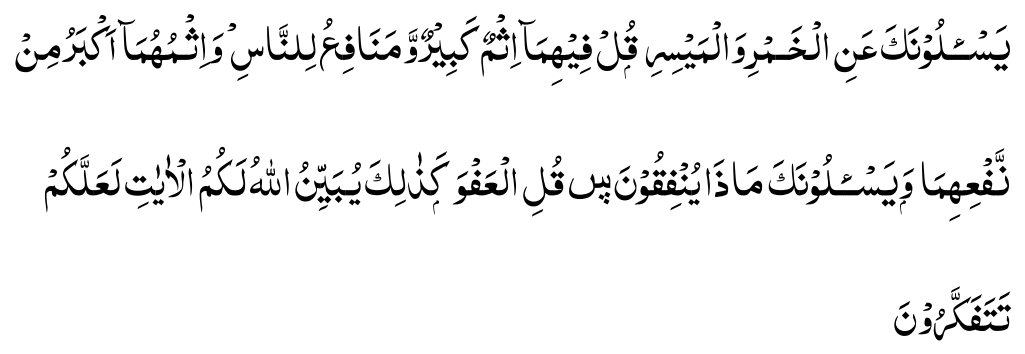

They ask you about wine and gambling. Say, In both there is great sin, and some benefits for people. And their sin is greater than their benefit. And they ask you as to what they should spend. Say, The surplus . This is 
The Scholar Islamic Academic Research Journal

Vol. 7, No. 2 || July-December 2021 || P. 58-77

https://doi.org/10.29370/siarj/issue13aren4

how Allah makes His verses clear to you, so that you

may ponder. ${ }^{18}$

In e-commerce gambling seems to be prevailing in giant e-commerce countries like China. ${ }^{19}$ There are online-casinos and gambling points where a person either wins a prize or losses his assets. Gambling and betting are forbidden in Islam in every form.

\section{PROHIBITION OF GHARAR (DECEIT)}

Gharar literally translates to "uncertainty, danger, or hazard." Gharar may occur in the selling of a possible item whose presence or attributes remain unknown due to the dangerous aspect of the transaction, which makes it comparable to gamble. Gharar is an Arabic term which meaning implies deception, danger, deceit, ambiguity, or peril that could result in devastation or harm. In Shariah, gharar means any contract involving possible items whose appearance or presentation is uncertain due to a lack of information and understanding about the contract's eventual result or the scope and characteristics of the agreement's particular subject. Abu Hurayrah (may Allah be pleased with him) narrates that

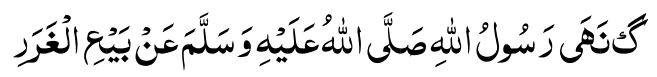

Holy Prophet (peace and blessings of Allah be upon

\footnotetext{
${ }^{18}$ Al-Quran 219:2

${ }^{19}$ How China's e-commerce giants enable illegal online gambling - Nikkei Asia

https://asia.nikkei.com/Spotlight/Caixin/How-China-s-e-commerce-giantsenable-illegal-online-gambling Accessed: 2021-11-01
} 
The Scholar Islamic Academic Research Journal

Vol. 7, No. 2 || July-December 2021 || P. 58-77

https://doi.org/10.29370/siarj/issue13aren4

him) forbade the sale of gharar... ${ }^{20}$

The scope of "Gharar" is broad as it includes any trade in which one deceit the others, this forbiddance can apply to that as fraud in any business transaction is prohibited.

ISLAMIC CONTRACT LAW AND ECOMMERCE- PROTECTION OF RIGHTS OF SELLER AND BUYER:

Islamic contract law is comprehensive and practical in the sense it protects the rights and interest of both the seller and the buyer. Contract law in Islam based on "mutual consent", as mentioned in Quran,
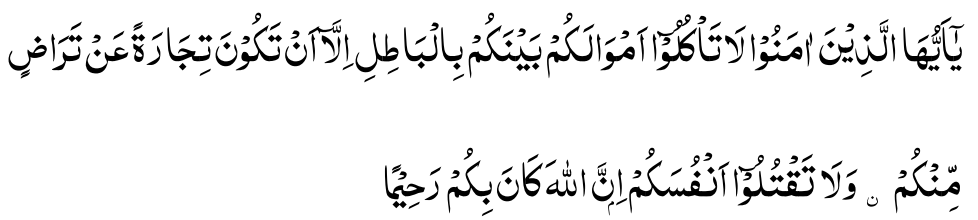

O you who believe, do not devour each other's property by false means, unless it is trade conducted with your mutual consent. Do not kill one another. Indeed, Allah has been Very-Merciful to you ${ }^{21}$.

In this verse, all activities that are against justice and are either lawfully or ethically repugnant are referred to be "False". 'Commerce,' on the other hand, refers to the mutual exchange of advantages between the parties involved, such as the one that underpins agreements in which one person

${ }^{20}$ Sunan Tirmidhi, The book of trades, Chapter 17, Hadith 1230

21 Al-Quran 29:4 
The Scholar Islamic Academic Research Journal

Vol. 7, No. 2 || July-December 2021 || P. 58-77

https://doi.org/10.29370/siarj/issue13aren4

gives whatever meets the wants of another and is

compensated in exchange. ${ }^{22}$

In Islam, mutual consent is not necessary only for doing a contract but it is also required for ending a contract. A person is not authorized to end the contract without letting the other partner know. It is narrated on the authority of Abu Hurairah (R.A) that the Holy Prophet (PBUH) said: The buyer and seller should not separate from a contract except from the mutual consent. ${ }^{23}$

In online busine things are also sold by mutual consent as whenever someone by a product on website there comes a popup "Do you agree?" or "Confirm Order" etc. But Shariah gives a proper way to return the products. In E-commerce return policy is contradictory in many ways. Islam gives the option of "Khiyar" to buyer and seller. Narrated Abdullah ibn Amr ibn al-As: The Prophet said:
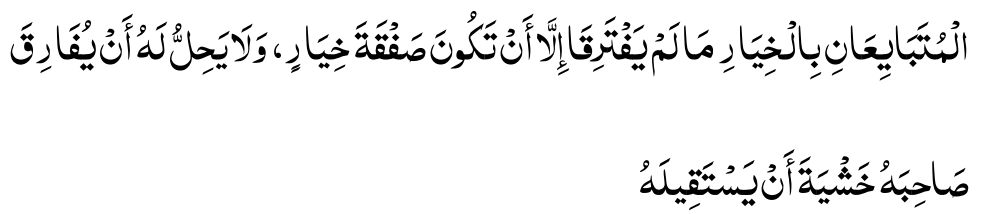

Both parties in a business transaction have a right to annul it so long as they have not separated unless it is a bargain with the option to annul is attached to it; and it is not permissible for one of them to separate from the other for fear that one may demand that the bargain be

\footnotetext{
${ }^{22}$ Kambol, "E-Commerce in the Context of Islamic Law of Contract of Sale."

${ }^{23}$ Sunan Tirmidhi, The book of trade, Chapter 27, Hadith 1248
} 
The Scholar Islamic Academic Research Journal

Vol. 7, No. 2 || July-December 2021 || P. 58-77

https://doi.org/10.29370/siarj/issue13aren4

rescinded. $^{24}$

So, according to Islam one has the right to annul his contract until they are in the same meeting. There is exceptional case to withdraw the agreement if one gives "Khiyar" (Power to Annul”, to other. ${ }^{25}$ Islam provides five khiyar in contract. $^{26}$ In e-commerce contract, there must be options like "Khiyar" to protect the rights of buyer.

\section{CONCLUSION AND RECOMMENDATIONS}

E-commerce is becoming more popular around the world, but many Muslim people are still ignorant of the validity of their activities from an Islamic point of view and in terms of Islamic corporate ethics. The validity of E-Commerce in Islam is investigated in order to inform Muslims all over the world about how they might benefit from this new technology if it is proven to be lawful and appropriate in Islam. In terms of transactions, the challenges of money transactions will be investigated to dispel Muslims' concerns about the Islamic prospects of E-Commerce. Purchases are done online, the medium of transaction or the internet, and the epayment mode are just a few of the new issues that demand Islamic researchers to widen the scope of description well beyond the usual sense. A shariah-based civilization is built on the principles of integrity, fairness, and equality, and it is unforgiving of all sorts of deception. It's why the Messenger of Allah places such a high value on total sincerity in commerce and fairness in trading. Ultimate integrity in trade and business

\footnotetext{
${ }^{24}$ Sunan Abu Dawood, The book of Ijarah, Chapter 17, Hadith 3456

${ }^{25}$ Sunan Abu Dawood, The book of Ijarah, Chapter 17, Hadith 3454

${ }^{26}$ Five Khiyars - IslamicMarkets.com https://islamicmarkets.com/education/five-khiyars Accessed: 2021-12-01
} 
The Scholar Islamic Academic Research Journal

Vol. 7, No. 2 || July-December 2021 || P. 58-77

https://doi.org/10.29370/siarj/issue13aren4

is truly an Islamic principle, it is not an understatement to claim. Islam is adamant in its opposition to economic fraud. It criticized all kinds of shady dealings and unlawful earnings in the fiercest ways imaginable. It has prohibited all activities that are not based on truth and fair play. To conclude, it is decisive to comprehend that developing a modern Islamic community does not necessitate the development of wholly new procedures. Innovative approaches, if utilized correctly and in the proper mix, may be able to accomplish the goal. Muslim economic experts can adopt necessary modifications in the structure of E-Commerce and form new strategies for online business transactions to serve the Muslim world in accordance with Shariah. 